\title{
st \\ The becoming of the experimental mode
}

\author{
Astrid Schwarz
}

\begin{abstract}
$\ddot{\sim}$
ABSTRACT

Francis Bacon's experimental philosophy is discussed, and the way in which it not only shapes scientific methodology but also deeply pervades all philosophical and social learning. Bacon draws us in to participate in an experiment with experience. The central driving force is the idea that learning how to learn is necessary in order to know. To meet this requirement, he considers the relation of form and content of pivotal importance, and therefore the selection of the literary form and the form of data inscription is decisive in the construction of a heuristic tool. His inductive method serves a dual purpose: first, the socalled indicative form aims at securing knowledge by a comprehensible procedure that controls and guides hypothetical thinking. Second, the literary forms "fragment" and "aphorism" embody the subjunctive, and invite intellectual openness and even speculation. In this article, special emphasis is put on Bacon's use and justification of the aphorism. Bacon's pervasive experimentalism meets in some sense today's broad adoption of the experimental mode. His philosophy calls for an ontology that is also at work in recent notions of co-action and co-working, or of affordance.
\end{abstract}

KEYwords $\bullet$ Experimentalism. Experience. Bacon. Literary form. Aphorism. Induction. Technoscience.

Bacon's Organon soll eigentlich ein heuristisches Hebzeug sein.

Bacon's Organon should really be a heuristic hoist.

Georg Christoph Lichtenberg, 1994, p. 830 [J 124,2].

\section{INTRODUCTION}

In the 1980s, philosopher Ian Hacking advocated rethinking the role of hands and eyes in the building of scientific knowledge. His Representing and intervening is one of the first and today most quoted philosophical books that urged paying more attention to experimentation, because it "has a life of its own" (Hacking, 1983, p. 150). Accordingly, in chapter 9, "Experiment", he starts with a vigorous statement about the blind spot of philosophers of science, who "constantly discuss theories and representation of reality, but say almost nothing about experiment, technology, or the use of knowledge to alter the world" (p. 149). And a few pages later: "What is scientific method? Is it the experimental method? The question is wrongly posed. Why should there be the 
method of science? We should not expect something as motley as the growth of knowledge to be strapped to one methodology" (p. 152). His statement about the importance of experimentation and a plurality of methodologies is accompanied by the hope that he might launch a "back-to-Bacon movement, in which we attend more seriously to experimental science" (p. 150).

Hacking was not the first philosopher of science to point to the importance of Bacon's conception of experience through experimentation. Karl Popper, Thomas Kuhn and Paul Feyerabend referred to it sympathetically and critically. Writing almost three decades later, however, one has to acknowledge Hacking's tremendous success in drawing attention to this Baconian idea, so much so that today Francis Bacon is the historical witness most often called upon in the characterization of recent transformations in construing and justifying knowledge, and its epistemological and ontological status (cf. Urbach, 1987; Krohn, 1990; Jardine \& Silverthorne, 2000; Zittel, 2008). To describe the "current state of human affairs in the wake of our collective Baconian transformation" (Muntersbjorn, 2002, p. 1141) is just one phrasing; reading Bacon as a precursor to Latour is another rhetorical strategy (cf. Urbach, 1987). Certainly, Bacon has become a lauded philosophical figure for having endorsed a range of claims concerning the origin of an experimental philosophy, the equality of applied and pure sciences, and the entanglement of politics, society and science; and, last but not least, he is cast as the founder of the inductive method and sometimes as an advocate of inductive logic. We see, then, that there is a rich and fascinating diversity of ways to understand Bacon's contribution, and with historical variations; for instance, reading Bacon as a representative of an inductive science was much more pronounced in the $19^{\text {th }}$ century than it is today.

Without proposing to offer an exclusively valid or exhaustive scheme, philosopher Madeline Muntersbjorn identifies four different "-isms" that are indicative of how Bacon's work has been perceived over time. Bacon as adhering to naive empiricism, as being a pioneer of inductivism and innovator of experimentalism, and, developing her own vantage point, as presciently anticipating constructivism. This conceptual scheme underlies her proposal that not only is it valuable to critically assess the different philosophical positions that were developed in the course of the history of Bacon's reception, but that this plurality helps us to "recognize the mutually sustaining and jointly necessary character of multiple methodologies within the scientific enterprise" (Muntersbjorn, 2002, p. 1139).

In the paper, I develop Muntersbjorn's proposal, and extend it by suggesting that all four labels can contribute to a better understanding of Bacon, if each is used as a kind of magnifying glass that helps to locate the critical incompleteness of the other ones. Its ambition is to use the perspectives thus obtained in order to gain richer in- 
sight into Bacon's ambiguous and seemingly inconsistent philosophy and, in so doing, to bring to the forefront the role of Bacon as an innovative experimentalist inside and outside the walls of the laboratory (or rather alchemist chamber). How do we experience at all? What about the extension of experience through instruments? And where does the question about the role of hands and eyes come in? The central driving force in Bacon's philosophy is the idea that learning how to learn is necessary in order to know, and he proposes a couple of innovative tools that help to span the tension between systematic reliability and challenging openness. Keeping this necessary tension in mind, I will discuss the literary forms of aphorism and metaphor, Bacon's focus on "experience becoming literate", and his conception of recording instruments (and their development), that is, of tools for inscription and rhetoric of the scientific experience. This is guided by my goals of scrutinizing the notion of the technoscientific object (cf. Schwarz, forthcoming), and of having a closer look at the early conditions of the sciences a long time before the institutional divide into lab and field sciences was established. However, what I pursue is just another fragment not a full picture of $\mathrm{Ba}-$ con's philosophy, hopefully one that provides hints for further work that will develop the picture more fully.

\section{A statesman doing NATURAL PHilosophy}

In the philosophy of science two of Bacon's books have received special attention: New Atlantis (1627) and what is referred to as Novum organum (2004, [1620]). Both are mainly concerned with questions about natural philosophy, about knowledge in what might be called theoretical and applied sciences, and about epistemological, and ontological and theological questions. Maybe one might argue that the utopian New Atlantis is the literary experiment of what is methodologically developed in the Novum organum. However, it is important to keep in mind that Sir Francis Bacon, Baron of Verulam, Viscount St. Albans, was not primarily a philosopher; rather, having been trained as a lawyer, he made an impressive political career that included a couple of years serving as an advisor to Queen Elizabeth I and then as Lord Chancellor for King James I. The Novum organon was published during the time in which he held the latter mandate. Accordingly it is the "Serenissimae Maiestati tuæ Seruus Deuinctissimus et Deuotissimus, Franciscus Verulam, Cancellarius", who asks the "wisest and most learned of kings" to tackle this "regeneration and instauration of the sciences" and to give his support by

put in hand the collecting and perfecting of a true and rigorous natural and experimental history which (...) may be designed for the building up of philosophy 
(...) so that at last (...) philosophy and the sciences may be no longer an airy and floating fabric but a solid construction resting on the firm foundations of well weighed experience of every kind (Bacon, 2004, [1620], p. 7 ff.).

It has been maintained that Bacon's juridical background is relevant not only for methodological and institutional questions (cf, e.g. Zittel et al., 2008) but also for the literary form chosen in the Novum organon (cf. Jardine, 1974; Schildknecht, 1995; Muntersbjorn, 2002). His juridical formation might have been also the reason for his familiarity with the idea of testing evidence in a public venue such as a court. It was highlighted that, throughout the centuries, there has been a close link between methods of obtaining and controlling evidence when dealing with the laws of nature in natural philosophy and the laws of men in the court. Nature, like a delinquent in the court, was to be investigated using a methodology that enables access to and supervision of the production of truth and knowledge. Interestingly, Bacon's method, both at the court and in his scientific work, appears to be more democratic than earlier scholastic methods, even though information gathered has to be explained by an elite cadre of interpreters. Bacon believed that in a court "ideas should be controlled by those whose position as custodians of the peace and security of the commonwealth best assured their credibility" (Ede \& Cormack, 2004, p. 144 ff.). Similarly, he believed that the "Idols", the prejudices and preconceived ideas through which human beings observe the world, have to be supervised by investigating, in a controlled environment, small bits of nature, which are then explained by skilled interpreters. Accordingly, for Bacon treason and heresy were similar to the Idols: all of them had to be unmasked, subordinated and controlled - and torture was considered a reliable means of obtaining evidence. This modus operandi of discerning and managing, in a sense governing, the truthful knowledge by scholarly “custodians”, and also Bacon's intimacy with executive power, distinguish him as a "courtly philosopher". 1

Some historians argue that Bacon might be more correctly regarded as a philosopher interested in theoretical models than as a "courtly philosopher"; but, at the same time, they acknowledge that he was deeply interested in the practical application of knowledge and also was sympathetic with "the rhetoric of utility so well-employed by Galileo" (Ede \& Cormack, 2004, p. 145). The ambiguity of their interpretation seems to attest to what probably can be considered the characteristic feature of Baconian philosophy: its systematic experimental character in form and contents - principally the literary form of aphorisms, and the systematic incompleteness of many parts of his

1 For a historical argument supporting the continuity of the analogy of laws of men and laws of nature, cf. Golan (2004). 
work concerned with natural philosophy. Sociologist Wolfgang Krohn argues that Bacon must have known that the plan of the Great Renewal [Instauration] was unworkable, that it could not be carried to completion either by one single person or to its full extent, because he wanted his philosophy to be "not only a science of words (Wortwissenschaft) but also an experimental science" (Krohn, 1990, p. xxxi). Thus, the New organon had to provide the logical tool box for the Great Renewal, which was intended to include not only the recollection of as many documented known facts from literature as possible, but also - and mainly - new known facts extracted from nature by experiment and observation. Its incompleteness in both form and content present a challenge to realizing the Baconian project of a permanent reconfiguration of experience, things and axioms. The reader is provoked to figure out a sound strategy for interpreting the bits of text and the overall scheme of the collection of texts - analogous to the naturalist or scientist who is asked to search for a "middle path" that permanently navigates between, on the one hand, collecting bits of nature and, on the other hand, questioning the Idols and scrutinizing the axioms. One might say that the experimental approach for testing theories propels the Baconian project. However, this "middle path" is not just an epistemological conception of the New organum, but in a sense it forms the backbone of Bacon's entire programme of how research should be exercised, namely being "interpretatio" and "operatio", "facere" and "intelligere", "scientia" and "potentia". It is a program that aims at pure and applied research, practice and theory, knowledge and power. In fact, the slogan "knowledge is power", so often attributed to Bacon, is mistaken, at least if it is applied to his conception of nature. Instead, he emphasizes that both, human science and human power, refer to each other and in the end come together: "Human knowledge and power come to the same thing" (Bacon, B, 1, p. 65, a. 3). ${ }^{2}$

It is symptomatic of Bacon's conceptual framing that he puts an emphasis on the balance of practical and intellectual skills. He suggests: "Neither bare hand, nor unaided intellect counts for much; for the business is done with instruments and aids, which are no less necessary to the intellect than to the hand" (B, 1, p. 65, a. 2) and even more "for what is most useful in operating, is most true in knowing" (B, 2, p. 205, a. 4). Because Bacon gives so much importance and weight to the hand, it seems proper to stress that in his work the "traditional tension between perception and concept is replaced by the one between practice and concept" (Krohn, 1990, p. xvi). ${ }^{3}$ This viewpoint implies the inescapable interdependency of finding and inventing things; and it

2 In a translation dating from 1676 , it says "things are performed by instruments and helps". One might argue that this shifts attention more to the item afforded than to the process (that is the business).

3 Krohn continues "(...) and it is to be clarified how the inner coherence between interaction with nature and interpretation of nature looks like" (1990, p. xvi). This corresponds quite well to the conceptual distinction of invention and finding in the following. 
renders Bacon especially interesting for recent philosophical discussions dealing with conceptions such as "thing knowledge" (Baird, 2004) or "technoscientific things" (Bensaude-Vincent et al., 2011). Bacon's "middle path" is not only a recurrent concept in his work but also an epistemological method. Consequently, it raises questions not only for philosophy of science but also for natural philosophy; and it offers both epistemological and ontological answers to them.

\section{The VISION OF A LEARNING SOCIETY}

The New organon is a philosophical treatise that is intended to provide a methodological infrastructure for a renewal of philosophy, that Bacon began in the incomplete, but impressively voluminous opus, the Instauratio magna, which contains the program of a Great Instauration or Great Renewal. It may be seen as a follow-up to The twoo bookes of Francis Bacon. Of the proficience and advancement of learning, divine and humane, published in 1605 and traditionally known as The advancement of learning (Bacon, 2000 [1605]). This is Bacon's principal philosophical work in English, and it "announces Bacon's comprehensive project to restore and advance learning" (Kiernan, 2000, p. vii). There is no doubt that Bacon had an encompassing vision about learning, of what should be learned, how and where it had to be pursued, and by whom. One might say that the huge work of the Instauratio magna was driven by Bacon's passion not only to understand learning but also to implement it as the driving force in society. It includes a description of the cognitive processes, considers their implications for a systematic design of knowledge, and gives a quite detailed plan of institutions required to implement the proper conditions for learning in society: "my hope is, that if my extreame love to learning carrie me too farre, I may obtaine the excuse of affection; for that it is not granted to man to love, and to bee wise" (Bacon, 2000 [1605], 4, p. 61).

The complete opus, Instauratio magna (Bacon, 2004 [1620]), consists of six parts, of which the New organon is the second and incidentally the only complete part. 4 The fragmentary character of the entire program, as well as the aphoristic form of the New organon itself, already mirror in some sense Bacon's belief in the power of the mode of experimentation, and therefore an estimation of the openness of the endeavour of a "universal description of the knowledge or learning which the human race at

4 The parts given in Distributio operis are: (1) The partitions of the sciences; (2) Novum organum, or Directions concerning the interpretation of nature; (3) The phenomena of the universe, or Natural and experimental history for the building up of philosophy; (4) The ladder of the intellect; (5) Precursors, or Anticipations of the philosophy to come; (6) The philosophy to come, or the Active science. Parts (1) and (2) were published in 1620, as well as the Preliminaries to part (3) and the Preliminaries to Instauratio magna. 
present possesses" (B, 1, p. 27; emphasis added). From this it also becomes obvious that "general description of the science" is to be taken quite literally. A prevailing interpretation misconceives Bacon, in the New organum, as a philosopher dealing primarily with epistemological questions in what is just a theoretical work. Instead, about half the book consists of numerous examples drawn from the so-called applied sciences; and this might be taken as further evidence for his practical perspective on experimentation and observation. The New organon was to be the new "tool" to control and acculturate nature - in whatever context. The fragmentary character of most of the parts of the Great Renewal, one might say, represents an experimental habit that reflects Bacon's conviction that wherever one starts to investigate nature, and to arrange the incremental pieces of information in a methodologically comprehensible order (for instance a tabular form), these acts will give raise to (at least partial) explanatory power.

The title and plan of the incomplete third part of the Great Renewal, "Phenomena of the universe", is particularly telling and exemplary for the argument that incompleteness was for Bacon, not mainly a deficiency or even flaw, but rather a necessary expression of his "method", and in some ways representative of it. This third part was to be a comprehensive compilation of "every kind of experience, and the sort of natural history which can establish the foundations of philosophy" (Jardine \& Michael, 2000, p. viii). The compilation of natural-historical data would include not simply data concerning different kinds of natural phenomena - a "history of the heavenly bodies, meteors, the earth and sea, minerals, plants and animals" (B, 1, p. 39) but also available data and descriptions in literature, all the knowledge from existing academic disciplines and from existing histories of crafts and trades. In short, Bacon's plan was to include all knowledge about nature. It is important to note that Bacon was convinced that intervention in nature, and thus doing experiments, "the vexations of art", would reveal the secrets of nature much better then observing how they "do in their usual course" - just as in "affairs of state we see a man's mettle and the secret sense of his soul and affections better when he is under pressure than at other times" (B, 1, p. 157, a. 98).

The fourth and vaguest part of the collection is of special interest here because it was intended to be an implementation of the method developed in the New organon, an "intellectual machinery" comprising axioms and observations "adjusted to the inductive method", and thus arranging and setting the stage for the material in a way that finally would allow "mankind unlimited power to control the natural world not by coercion but by complete understanding" (Jardine \& Michael, 2000, p. xiv). Thus, Bacon makes a suggestion of how the material ought to be arranged, and how the intellectual machinery should be used, to finally overcome the resistance of the natural world. Small bits of nature should be drawn into the controlled world of recording and experimen- 
tation, and transformed into artefacts, as Bacon famously said, like a bee "which collects its material from the flowers of field and garden, but its special gift is to convert and digest it" (B, 1, p. 153, a. 95). This model together with the "intellectual machinery" is extremely powerful in Bacon's writings. Together, they pave the way for a conception that Bacon envisioned as the "true job of philosophy", that is, to develop a "middle path" between the traditional philosophical positions "empirics" and "rationalists" (coming close to today's terminology of realists and constructivists). As Bacon puts it: "The empirics, in the manner of the ant, only store up and use things; the rationalists, in the manner of spiders, spin webs from their own entrails; but the bee takes the middle path: it collects its material from the flowers of field and garden, but its special gift is to convert and digest it" (a. 95). Bacon advocates for a closer alliance of the two faculties, the experimental and the rational; and in trying to bring about this alliance, and finally succeeding, we have reason for "good hopes".

\section{AN AGTIVE FORM OF LEARNING: FRAGMENTS AND APHORISMS}

In addition to the conspicuous and somehow consistent incompleteness of the Great Renewal, a second formal means of openness, the literary form of aphorisms, calls for an exploratory reading. The aphorism, together with the formal system and the dialogue, may be looked at as the literary forms that have fundamentally shaped the genre of philosophy of science. After Bacon, philosophers and scientists such as Blaise Pascal, William Whewell, Georg Christoph Lichtenberg, Arthur Schopenhauer and, maybe most known today, Ludwig Wittgenstein wrote at least a part of their philosophical works in aphoristic mode. Aphorism and scientific fact have some similarity, both can be looked at as appearing in an experimental setting. "The dramatic appearance of a fact on the stage of an experiment is supposed to have the rhetorical force of dispelling the doubt of skeptics. The aphorism works in a similar way in that it presents a thought solely for its power to unsettle belief or to suggest a possibility" (Nordmann, 2010, p. 368). Sharing a rather abrupt appearance on the scene, fact and aphorism nevertheless differ in their gesture. The fact rather pursues an experimental situation to its conclusion, and it does so by allying himself with theory, as William Whewell put it so aptly "we do not see them [the facts], we see through them" (Whewell, ${ }_{18} 5^{8}$, p. 44). The corroborated fact is the currency of the learning process that drives the experiment and the emerging fact brings this process to a conclusion and settles it down.

In contrast, aphorisms invoke possibilities, they open up the arena of thoughts and imagination. An aphorism might even be confounding: aphorisms provoke speculative thinking, including thought experiments. The openness of Bacon's aphoristic 
style might be looked at as an invitation to get involved in the method he advocates and practices (cf. Muntersbjorn, 2002, p. 1142; Schildknecht, 1995, p. 29 ff.). The reader is urged into an active role while trying to make sense of the ambiguous and apparently contradictory aphorisms. One starts to build hypothesis, and to arrange combinations of possible expressions, in order to make sense of the bits of text - just as a natural philosopher ought to do with the small bits of nature that are to be combined in a distinct order so as to reveal the causes that rule nature. 5 Not only does the reader experience intuitively the openness of the method, but his attention is likewise drawn to the process, rather than to the end of knowledge production. Bacon himself defines aphorisms in exactly these terms, as "brief and scattered sentences, not restrained by rhetorical method" (B, 11, 1, p. 139, a. 86). He was fully aware of the heuristic character of the aphorism. If heuristics is the "ars inveniendi", the art of inventing or finding/discovering (Erfindungs-Findungskunst), the aphorism is the literary form that perfectly represents this openness and infinite search for novelty. Bacon suggested that while knowledge "is in aphorismes and in observations, it is in groweth; but when it once is comprehended in exact methodes; it may perchance be further pollished and illustrate, and accommodated for use and practise; but it increaseth no more in bulke and substance" (Bacon, 2000 [1605], p. 30). Bacon appreciates the necessary indeterminacy of the aphoristic mode. The aphorism, and with it the grammatical form of the subjunctive, becomes a central literary form in his philosophy representing his experimental practice. This was finally the decisive step that also "hoists" Bacon's program out of the Renaissance context and into the Enlightenment way of thinking (cf. Schöne, 1982; Steinle, 2006).

Bacon himself was aware of the ground-breaking character of his program. He was the first philosopher who described his own philosophy as a "revolution", suggesting that his thought might be viewed as analogous to a political overthrow (cf. Krohn, 1990, p. xxix). However, Bacon's revolution is certainly not to be restricted to the contemporary meaning of a rather circular turnover of incidences. Instead, it involved already an idea of change that comes close to the modern idea of scientific progress that involves transcending prevailing social and scientific conditions.

5 Following the dominant metaphor "book of nature" and the philosopher as the skilled interpreter of this book, Bacon assumed a close similarity of language and the order of nature, while comparing the diversity of natural processes to the diversity of written expressions. He expected that the former can be explained by a small number of causes just like the latter can be by the combination of a given number of letters. This idea was in some sense taken up in the artificial language movement in seventeenth-century England (cf. Lewis, 2007). Interesting enough Bacon thought that this endeavour would be manageable in a few years if it was only allowed a sufficient amount of funding (cf. Farrington, 1951). This is clearly an estimation from the naive empiricist Bacon. 
The German physicist and philosopher Georg Christoph Lichtenberg, with his aphorism "Bacon's Organon should really be a heuristic tool" 6 explicitly suggested that Bacon proposed a renewal of scientific method through his emphasis on the experimental and hypothetical character of knowledge. Bacon proposes with his inductive method to start with sensuous perception, to advance to singular instances and after having secured these systematic observations in written records to finally conclude with general sentences (cf. Krohn, 1990, p. xix). The condition of learning according to Bacon, especially of scientific learning, is therefore to have an intellectual tool at hand that makes invention possible. The subjunctive is the perfect linguistic form to express this permanent transgression of the limits of prevailing knowledge because it points to the space of possibilities. No wonder, that Lichtenberg finds support in Bacon's programme for his own "cardinal scanning formula (...). To invent a finder for all things". . It is precisely the "finder", the "Tubus Heuristicus" as he specifies, that invokes the "sceptical, hypothetical, experimental subjunctive" (Schöne, 1982, p. 76), that is the elementary form of any heuristic methodology in the art of finding. However, there is another interesting connection here that is the closeness of discovering/ finding and inventing things and also the ambiguous character of the finder, being a theoretical and a practical tool.

It seems significant to note, that Bacon challenges his readers not only to tolerate the uncertainty that comes along with the openness of his program, but in a sense he draws them in to become active participants in the implementation of the Great Renewal, insofar as they already contribute to the endeavour just by reading and trying to make sense of it. One might be tempted to make a big leap into the 2oth century and apply to the ideal Baconian reader Popper's offensive "heroic and romantic" characterization of great scientists as "men who humbly devoted themselves to the search for truth, to the growth of our knowledge; men whose life consisted in an adventure of bold ideas" (Popper, 1974, p. 977) ${ }^{\mathbf{8}}$ - in short, people that are involved in an openended scientific enterprise and driven by a passion for learning and knowledge growth.

\footnotetext{
6 In translating Lichtenberg's aphorism at the outset of the article, I used "hoist" instead of "tool". Either word is equally adequate, but perhaps "hoist" does more justice to the historical context.

7 Schöne denotes the aphorism "Einen Finder zu erfinden für alle Dinge" [J 16211] as the "kardinale Suchformel" of Lichtenberg. The directly following note in Lichtenbergs Sudelbücher is "Ein Tubus Heuristicus" [J 1621] (Lichtenberg, 1994, 2, p. 297).

8 Popper himself would have certainly objected to see his hero scientist so close to a "naive empiricist". However, Popper acknowledged Bacon's active scientist (cf. Urbach, 1987), although how far from each other the seemingly fundamentally different strategies of the "adventure of brave ideas" and the search for the "middle path" really should remain an open question. Surely, he did overlook the accuracy that Bacon put in the development of intermediate means - his middle path - in the transformation of sense-data into experience.
} 
But the openness and dynamics in the formation of knowledge is just one side of the Baconian organon. There is always also a strong systematic power involved that gives the formation of knowledge structure and form. Historian Lisa Jardine points out that "the aphorisms of this method of presentation are not witty, anecdotal sayings", and that finally the progress of the discourse is afforded as a result of the "cumulative effect of the discrete aphorisms" (Jardine, 1974, p. 177). The aphoristic form helps "to spur the reader on to similar enterprises of his own" (p. 177), therefore, as already noticed, the reader experiences the method himself and in so doing he participates in the enterprise (cf. Krohn, 1990, p. xxxvii).

Just as the fragmentary character and the aphoristic mode are supporting forms of a necessarily partial systematic order, the literary form of metaphor and what Bacon calls "written experience" are important heuristic tools in his work. The latter is probably the most elaborated formal tool in his methodology and intimately linked to his method of induction. Written experience requires the development of a practice of taking and representing records - including making notes and tables, and Bacon gives a lot of attention particularly to the latter. However, making notes and tables does not just shape experience. Rather the "experience becoming literate" is the precondition for scientific work, for making scientific discoveries, for performing scientific experiments, and for developing scientific knowledge.

\begin{abstract}
And yet so far mental effort has had a much more important part to play in discovering than has writing, and indeed experience has yet to be made literate. And no discovery should be sanctioned save that it be put in writing. Only when that becomes standard practice, with experience at last becoming literate, should we hope for better things (B, 1, p. 159, a. 101; emphasis added).
\end{abstract}

\title{
4 EXPERIENTIA/EXPERIMENTUM
}

The terms, "experientia" and "experimentum", pose difficulties for translation. In the Middle Ages "experientia" denoted experience in general, whereas "experimentum" denoted particular instances that were to be described in a generalised and impersonal literary form (cf. Steinle, 2006, p. 723). Bacon used the two words only slightly differently "both for the unforced observation which we might call experience and for the contrived experience which we might call an experiment" (Jardine \& Silverthorne, 2000, p. 57). This concept of experiment is clearly different from the one being employed in recent times, even in light of the polysemantic character of the word. 
The beginning of the Modern Age is marked by an important break, substantially induced by Francis Bacon; it involves a new understanding of experience, and to a lesser extent of experiment. Accordingly, the most important difference of Bacon's scientific method compared to that of his predecessors - and also of many successors - is the clear commitment to the new role of experience and its formalisation. Form is a causal structure for Bacon: "for the form of any nature is such that if it be in place the given nature invariably follows" (B, 2, p. 205, a. 4). However, the understanding of experiment is also modified. An experiment not only demonstrates a conclusion suggested by systematic and deductive reasoning, but it also generates new knowledge. Bacon expected that the process itself - the collecting, listing and organizing of empirical data - would lead to entirely new and unforeseen theories. He was fully aware of the momentous significance of the break, and of the profound problem to bridge it by means of communication. "Nor is it easy to pass on or to explain what I have in mind, for people will still make sense of things new in themselves in terms of things which are old" (B, 1, p. 77, a. 34). Bacon proposes to address this cognitive paradox, and the subsequent linguistic incompatibility, by applying the new method itself. The reflexive step is complemented by the new practice of perception and thus performs the change of experience in experiencing. "In fact, I have only one simple way left for conveying what I have to say; to lead men to the particulars themselves and their succession and order, and get them in turn to repudiate their notions for a while, and begin to grow used to things themselves" (B, 1, p. 77 ff., a. 36).

Again, one is tempted to say that Bacon calls upon a modern subject, an autonomous and critical mind, as "a genuine midwife of modernity". 9 This claim has been made particularly by sociologists of science who have represented Bacon as a forerunner of their discipline, suggesting that he was one of the first thinkers to have a cooperative science-based vision of societal welfare (cf. Krohn, 1990, p. xxx). In fact, however, Bacon's fierce critique of what he called the "Idols" can be seen as a critique of ideology, and the method of "true induction" was to be the appropriate means for "restraining the Idols and driving them off" in order to protect notions and axioms (B, 1 , p. 79, a. 4. 0 ). All of this just underlines the structural and also strategic importance of the method of induction in Bacon's work, and from this it becomes almost self-explanatory why he put so much precise detail into his justification of the formal and genetic development of this method. Accordingly, it is a fundamental concern of the New organon to offer a thoughtful conceptualization, mainly about the mutual impact of sensual perception and experience, of natural entities and scientific artefacts in order 
to pave the way to "a true and perfect axiom of knowing" of which the "precept is this: that there be discovered another nature which is convertible with the given nature, but which is nevertheless a limitation of one better known to nature like a true genus" (B, 2, p. 205 , a. 4).

The process of learning thus implies a connection of theoretical knowledge and practical knowledge, but the crucial point here is that true knowledge about nature cannot be acquired other than by intervention. The ars inveniendi allows for a discovery of "another nature", and by means of practical activities. By experimenting, we also get to know about "given nature", and finally we are led to the more general sentences (the axioms or laws). The description of dispositions of natural objects and the creation of an artificial effect are seen to be equivalent - we only know insofar as we can do. This is the core of the program to which Bacon gave a number of names such as "experimental philosophy", "scientia operativa", and "natural and experimental history" - a program with an emphasis on new innovations and discoveries and not on controversies (dialectics) or restricted to logical operations. Moreover, it requires a different perspective on the ontology of objects, according to which technical agency and natural agency are not separated categorically, as is usually done in scientific epistemologies (at least those more or less explicitly Kantian). When Bacon says that "the form of heat (...) is the same thing as the law of heat" and that he "never withdraw[s] or abstract[s] from the things themselves or the operative part" (B, 2, p. 255 ff., a. 17), this comes close to views expressed in discussions regarding technoscientific objects that are described as part of an "apparatus-world complex" (Harré, 2003), generated in "phenomenotechnological" processes (cf. Bachelard, 1938), and in the search for ontological categories such as the notion of affordance (cf. Gibson, 1979) in analysing these technoscientific objects.

With his concept of affordance, psychologist James Gibson offers a theory about dispositional properties, where things are looked at as objects with properties that are useful to their beholders and that thereby can become objects of design. For instance, water has the dispositional property to freeze at o degree centigrade and to form a layer of ice. This layer of ice affords skating. Gibson characterized the relation between an observer and his/her environment as a permanent experimental interdependence. "An affordance points both ways, to the environment and to the observer" (Gibson, 1979, p. 129); "perceiving is a psychosomatic act, not of the mind or of the body but of a living observer" (p. 24,0). In this sense, we might want to say that observations as well as experiments afford experiences. These experiences can then be written down in numbers which can be expressed as words or as figures: numbers can be used for either classificatory or mathematical purposes and both of these uses are equally valuable for the improvement of knowledge about natural things. The experimental character of 
"experience becoming literate" - virtually the instrument "inscription system" becomes even more apparent when it is construed as a heuristic tool. In this sense, writing down "words and figures" does improve a physical law or a botanical and zoological classification. What is more, it affords new systematic kinds that eventually enable the prediction of unknown things or species. This was precisely the role of the three types of tables that ought to make similarities of instances visible, to display deficiencies and gaps, and to finally allow to reject and exclude instances as the decisive step of an inductive inference that reaches more general axioms.

\section{HUMAN INTPLLLECT IS IIKE AN UNEVEN MIRroR}

Bacon was in no way naive about the reliability of sense-data and sensation, and thus about the biased conditions of experience: "in fact all perceptions of sense and mind are built to the scale of man and not the universe. And the human intellect is to the rays of things like an uneven mirror which mingles its own nature with the nature of things, and distorts and stains it" (B, 1, p. 81, a. 41); and even more explicitly: "the greatest hindrance and distortion of the human intellect stems from the dullness, inadequacy and unreliability of the senses" (p. 87, a. $5^{\circ}$ ); "(the sense) either deserts or deceives us" (p. 33). The use of instruments does not solve the problem of the "uneven mirror", because for "instruments to amplify and sharpen the senses do not count for much" (p. 87 , a. $5^{\circ}$ ).

Two elementary techniques help to make the method of induction, not only a good tool to get at novel knowledge, but the only truly reliable one that enables the "intellectual machinery" to "engage in things humble and transitory" (p. 87, a. 49) and by such doing to provide it with an operative power. The first technique is about transforming mere sensations into text, thus to secure the sense-data, to make the smallest bits of possible instances available, to transform them into comparable experiences and to assure the "experience becoming literate" for the memory archive. ${ }^{10} \mathrm{In}$ the second book of the New organon, Bacon suggests that a system of tables should provide an intelligible structure, and he provides an exemplification of his recording technique straight away. Instances of a property ("nature") - one of his two examples is heat - are to be collected and filled in a first Table of Essence and Presence; the second Table of Divergence or Absence in Proximity gives the uncertain or negative instances, and the third is the Table of Degrees or Comparative Table. The tables allow for a pano-

10 Remember his worry about the confusion and unreliability of data-inventory: "only when that becomes standard practise, with experience at last becoming literate, should we hope for better things" (B, 1, p. 159, a. 101). 
ramic view over a rather wild collection of known instances, but also "phantasms, mere opinions, ill-defined and notional conclusions, and axioms altered daily" (B, 2, p. 253, a. ${ }^{15}$ ). The tables afford a systematic order by rendering visible the similarities, the deficiencies and gaps; they enable rejection and exclusion of instances, which is "the first job of true induction" (p. 255, a. 16); and they provide a basis for further investigation and decision-making. The tables " $(p)$ erform an experiment or investigate further" (p. 253, a. 14). One might say that the aphorisms and metaphors are the subjunctive forms in Bacon's epistemology, whereas the tables and the logical procedures induced can be considered as the indicative forms. Offering a subjunctive form, aphorisms point to the space of possibilities, whereas the tables form part of the space of actuality/reality.

The inductive method obviously serves a dual purpose: first, the so-called indicative form aims at securing knowledge by a comprehensible procedure that controls and guides hypothetical thinking. "[T] he mind must surely be prepared and shaped in such a way as not to exceed due degrees of certainty, and yet understand (especially at the start) that what it has done very much depends on what it remains to achieve" ( $p$. 261, a. 19). Second, the literary forms "fragment" and "aphorism" which, as discussed earlier, embody the subjunctive, invite intellectual openness and even speculation. This is also the case with metaphors that are widely used by Bacon, especially where he considers metaphors as models such as in the already mentioned bee-model that serves to explain his "middle path".

This corresponds to another aphorism, but using a language that comes closer to an analytical style, where Bacon explains that the axioms are to be drawn "from the sense and particulars by climbing steadily and by degrees so that it reaches the ones of highest generality last of all; and this is the true but still untrodden way" (B, 1, p. ₹1, a. 19). Bacon points out that this is radically opposed to the methodological practice, then widely used, which, he critically notes, "rushes up from the sense and particulars to axioms of the highest generality and, from these principles and their indubitable truth, goes on to infer and discover middle axioms" (a. 19). Bacon also refers to his step-bystep method when he insists that the form - which is conceptualised as a material device (such as a table) - helps to keep the line between certainty and uncertainty about the value of an instance (or the particulars), and to decide if experiments ought to be done to further secure the epistemic procedure from the senses to instances to more general sentences - "only when we ascend the proper ladder by successive, uninterrupted or unbroken steps, from particulars to lower axioms, then to middle ones, each higher than the last until eventually we come to the most general" (B, 1, p. 161, a. 104). The quality of knowledge becomes a question of the quality of an epistemic chain that stretches from the sense-data, to the concepts or models, and finally to theories and 
laws or lawlike sentences. The connective power of this chain is that it can be traced in both directions securing the connection between higher axioms and instances and thus rise above mere speculation. ${ }^{11}$ Moreover, scientific practice solidifies the connection, because the intermediate axioms (the "middle path") also cast more importance on what, "men's fortune and affairs depend" and they are "not far from naked experience" (B, 1, p. 161, a. 104). It does not seem too much of a speculation to argue that the experiment has a decisive authority in Bacon's method of induction that can "make" these experiences and thus secure the step between the lower axioms and the most general ones. The experiment is the heuristic tool of an active scientist, it is a planned action in which instances of experience are brought forward, transformed into "experience becoming literate" and finally put on record in theories or entities of higher abstraction such as laws - and one is tempted to continue in Bacon's place: at least for some time being.

"Conducting experiments" signifies the process of giving form to experience and to permanently rebuilding and justifying the connection between finding and inventing things. The Baconian inductive method does not account for planing or glazing the "uneven mirror". Instead it is very useful to be aware of the scratches and blind spots in it and mainly to appreciate them as they are calling for a permanent improvement of ourselves and the affairs with our environment. For Bacon, the method of induction is a heuristic tool, but it is just a heuristic tool, based mainly on mechanisms of exclusion that is, it is primarily "eliminative induction" (Gaukroger, 2001, p. 138 ff.). Bacon's interest in the "negative cases" is driven by his belief that it is possible to find the ultimate explanations if we only succeed to weed out those factors that are not necessary for the production of an effect. Bacon is committed to an ontology of things. He is interested in laws and causal structures not merely to better understand the material world, but as a means to transforming nature for human purposes. "Lawlikeness is the crucial connection between our knowledge of basic structure and our ability to transform nature" (Gaukroger, 2001, p. 140). Moreover, his emphasis on art and labor for the manipulation of material and for affording things also makes Bacon's theory of the basic structure of things attractive for contemporary philosophers of science who discuss experimentation, technoscience and emerging technologies along with changing relations of science and society, innovation and utility. By the same token, Bacon is referred to by sociologists and political scientists; particularly concepts such as coproduction and co-action are of relevance here (cf. Jasanoff, 2006; Gill \& Borchers, 2008). And though Bacon's philosophy of science lacks perhaps the complexity and

11 As Bacon notes, "we should not supply the human intellect with wings but rather with leaden weights to curb all jumping and flying up" (B, 1, p. 163, a. 104). 
subtlety of more recent philosophies of science, his idea of a middle path involving matter and mind in equal measure in an ongoing process of inventing and systematizing things might be seen as one important building block of a philosophy of science that equally focuses on propositional knowledge and on the design of scientific things.

\section{Conclusion}

The metaphor of the "uneven mirror", the emphasis on the interdependence of finding and inventing things, and on the active role of perception, might thus be revitalized by relating it to recent philosophical discussion on the conception of affordance. Bacon does more than provide us with the historical definition of a scientific experiment - what he "called 'artificial experiments' became the model for 'experiment' tout court by around 1660" (Daston, 2011, p. 86). While the reduced notion of "experiment" as "artificial experiment" (under laboratory conditions) may have become common in science, it agrees neither with Bacon's pervasive experimentalism and today's broad adoption of the experimental mode. Moreover, it is too narrow also in respect to the multifaceted and differentiated accounts of experimentation in recent philosophy of science. Bacon's New organon draws us in to participate in an experiment with experience, and therefore challenges us to think about the condition of possibility of learning in a fundamental and radical sense. It suggests that the selection of form is decisive in the construction of a heuristic tool and calls for an ontology that is founded on notions of co-action, co-working and co-habitation, rather than categorical dichotomies. Accordingly, epistemic things are afforded, they are produced by scientists as they arise: "as for works man can do nothing except bring natural bodies together or put them asunder; nature does the rest from within" (B, 1, p. 65, a. 4). In this sense, Bacon certainly adds essential aspects to a philosophy of technoscience, more precisely, to a conception of technoscientific objects.

Acknowledgements. Thanks to Steven Tester for help in coping with the translation of Lichtenberg's aphorism, quoted at the outset, and to Kathleen Cross for revising the very first English version of this paper. Hugh Lacey's attentive reading and his sometimes uncomfortable, but always supportive comments, "hoisted" the manuscript considerably. Finally, I wish to thank Alfred Nordmann for the continuous discussions on "technoscience and..."

Astrid Schwarz Doctor, Institute of Philosophy, Darmstadt Technical University, Germany. schwarz@philo.tu-darmstadt.de 


\section{REFERENGES}

Bachelard, G. La formation de l'esprit scientifique. Paris: Vrin, 1938.

Bacon, F. Novum organum. London: Thomas Lee, 1676 [1620].

. The advancement of learning. In: Kiernan, M. (Ed.). The Oxford Francis Bacon. Oxford: Clarendon Press, $2000[1605]$.v. 4 .

Instauratio magna, part II. In: Rees, G. \& Wakely, M. (Ed.). The Oxford Francis Bacon. Oxford: Clarendon Press, 2004, [1620]. v. 11.

. New Atlantis. 1627. Available at: <www.gutenberg.net>. Accesed: 23/Oct./2008.

BAIRD, D. Thing knowledge: a philosophy of scientific instruments. Berkeley: California Press, 2004.

Bensaude-Vincent, B. et al. Matters of interest: the objects of research in science and technoscience. Journal for General Philosophy of Science, 42, p. 365-83, 2011.

Ctarke, B. \& Rossini, M. (Ed.). The Routledge companion to literature and science. London: Routledge, 2010.

Daston, L. The empire of observation, 1600-1800. In: Daston, L. \& Lunbeck, E. (Ed.). Histories of scientific observation. Chicago: The University of Chicago Press, 2011. p. 81-113.

Daston, L. \& Lunbeck, E. (Ed.). Histories of scientific observation. Chicago: The University of Chicago Press, 2011.

Ede, A. \& Cormack, L. B. A history of science in society. From philosophy to utility. Peterborough: Broadview Press, 2004.

Farrington, B. Francis Bacon: philosopher of industrial science. London: Lawrence and Wishar, $195^{1 .}$

Gill, S. B. (Ed.). Cognition, communication, and interaction: transdisciplinary perspectives on interactive technology. Dordrecht: Springer, 2008.

Gill, S. B. \& Borchers, J. Knowledge in co-action. In: Gill, S. B. (Ed.). Cognition, communication, and interaction: transdisciplinary perspectives on interactive technology. Dordrecht: Springer, 2008. p. 3855 .

Gaukroger, S. Francis Bacon and the transformation of early modern philosophy. Cambridge: Cambridge University Press, 2001.

Gibson, J. J. The ecological approach to visual perception. Boston: Houghton Mifflin, 1979.

Golan, T. Laws of men and laws of nature: the history of scientific expert testimony in England and America. Cambridge: Harvard University, 2004.

Hacking, I. Representing and intervening. Cambridge: Cambridge University Press, 1983.

HARrÉ, R. The materiality of instruments in a metaphysics for experiments. In: RAdDER, H. (Ed.). The philosophy of scientific experimentation. Pittsburgh: University of Pittsburgh Press, 2003. p. 19-38.

Jardine, L. Francis Bacon: discovery and the art of discourse. Cambridge: Cambridge University Press, 1974.

Jardine, L. \& Michaed, S. Introduction. In: Jardine, L. \& Silverthorne, M. (Ed.). Francis Bacon: the new organon. Cambridge: Cambridge University Press, 2000. p. vii-xxix.

Jardine, L. \& Silverthorne, M. (Ed.). Francis Bacon: the new organon. Cambridge: Cambridge University Press, 2000.

JASANOFF, S. States of knowledge: the co-production of science and the social order. London: Routledge, 2006.

Kiernan, M. Introduction to Francis Bacon, the advancement of learning. In: (Ed.). The Oxford Francis Bacon. Oxford: Clarendon Press, 2000. v. 4.

Kiernan, M. (Ed.). The Oxford Francis Bacon. Oxford: Clarendon Press, 2000. v. 4.

Квонм, W. Einleitung. In: Kвонn, W. (Ed.).F. Bacon, Neues organon: lateinisch-deutsch. Hamburg: Meiner, 1990. v. 1, p. ix-lvi.

Квонм, W. (Ed.).F. Bacon, Neues organon: lateinisch-deutsch. Hamburg: Meiner, 1990. 2 v.

LEWrs, R. Language, mind and nature: artificial languages in England from Bacon to Locke. Cambridge: Cambridge University Press, 2007. 
Lichtenberg, G. G. Schriften und Briefe. In: Promies, W. (Ed.). Sudelbücher. Frankfurt: Zweitausendeins, 1994. v. 1-2.

Muntersbjorn, M. Francis Bacon's philosophy of science: machina intellectus and forma indita. Philosophy of Science, 70, p. 1137-4.8, 2002.

Nordmann, A. Philosophy of science. In: Ciarke, B. \& Rossini, M. (Ed.). The Routledge companion to literature and science. London: Routledge, 2010. p. 362-73.

Popper, K. R. The problem of demarcation. In: Schilpp, P. A. (Ed.). The philosophy of Karl Popper. La Salle: Open Court, 1974. p. 976-84.

Promies, W. (Ed.). Sudelbücher. Frankfurt: Zweitausendeins, 1994. 2 v.

Radder, H. (Ed.). The philosophy of scientific experimentation. Pittsburgh: University of Pittsburgh Press, 2003.

RADMAN, Z. (Ed.). From a metaphorical point of view: a multidisciplinary approach to the cognitive content of metaphor. Berlin: Walter de Gruyter, 1995 .

Rees, G. \& WAKeLY, M. (Ed.). The Oxford Francis Bacon. Oxford: Clarendon Press, 2004 [1620]. v. 11. (B).

Schildknecht, C. Experiments with metaphors: on the connection between scientific method and literary form in Francis Bacon. In: Radman, Z. (Ed.). From a metaphorical point of view: a multidisciplinary approach to the cognitive content of metaphor. Berlin: Walter de Gruyter, 1995. p. 27-50.

Schilpp, P. A. (Ed.). The philosophy of Karl Popper. La Salle: Open Court, 1974.

Schöne, A. Aufklärung aus dem geist der Experimentalphysik. München: Beck, 1982.

Schwarz, A. Technoscientific objects. Poiesis \& Praxis. Forthcoming.

Steinle, F. Experiment. In: Enzyklopädie derneuzeit. Stuttgart, Weimar: Metzler, 2006. v. 3, p. 722-8.

URBACH, P. Francis Bacon's philosophy of science: an account and a reappraisal. Chicago: Open Court, 1987 .

Whewell, W. Novum organon renovatum (being the second part of the philosophy of the inductive sciences). 3 ed. London: Parker and Son, $185^{8}$.

Zittel, C. Introduction. In: Zittel, C. et al. (Ed.). Philosophies of technology. Francis Bacon and his contemporaries. Leiden/Boston: Brill, 2008. p. xix-xxix.

Ziтté, C. et al. (Ed.). Philosophies of technology. Francis Bacon and his contemporaries. Leiden/Boston: Brill, 2008. 